\title{
EFISIENSI PARASITISASI INANG SPODOPTERA LITURA (F.) OLEH ENDOPARASITOID SNELLENIUS MANILAE ASHMEAD DI LABORATORIUM
}

\author{
Endang Sri Ratna ${ }^{1}$
}

\begin{abstract}
Eficiency of parasitization on larval host, Spodoptera litura (F.), by an endoparasitoid Snellenius (=Microplitis) manilae Ashmead in the laboratory. The armyworm, Spodoptera litura (F.) is the host of an endoparasitoid Snellenius manilae Ashmead. This research described the effect of host larval stage preference, the number of host exposure and the age of parasitoid on the resulting parasitization. Each group of the first to the fifth of host instar (30 larvae) was exposed for 3 hours to a pair of four-day old parasitoids in a trial cage. The same exposures were conducted without choices by placing each instar group within each trial cage. The parasitoid survival was observed by maintaining the parasitized larvae until adult emergence. Each group of 10, 20,30 and 40 of the second instar larvae were exposed for 12 hours/day to a mated female parasitoid. This experiment was conducted from the first day old parasitoid until the females died. The percentage of parasitization, superparasitization, oviposition and the fecundity of adults were recorded. Each group of thirty second instar larvae was exposed separately to a mated female parasitoid of 1 to 9 days old. The survival of progeny was recorded. All treatments in this observation were repeated 10 times. S. manilae preferred to lay eggs on the third (41.7\%) followed by the second (22.3\%) instar larvae of S. litura. The lowest percentages of superparasitization obtained from the first and the second instar larvae were between 11 and $15 \%$ and the highest percentage of superparasitization obtained from the fourth instar larvae was $52 \%$. The highest survival of parasitoid was found on the exposure of the second instar larvae which reached $16 \%$. The highest efficiency of parasitism $(80.9 \%)$ was found on the twenty of the second instar larval exposure density which produced $59 \%$ of optimal parasitization level, the average rate of egg laid by females was 25 eggs/day, and the fecundity was 185 eggs/female. Female parasitoids of 1-7 days old gave the same opportunity to produce progeny survival which was in the range of $10.3-25.7 \%$.
\end{abstract}

Key words : oviposition-preference, host-suitability, efficiency, Snellenius manilae, Spodoptera litura.

\section{PENDAHULUAN}

Snellenius (=Microplitis) manilae Ashmead (Hymenoptera: Braconidae) merupakan endoparasitoid ulat grayak Spodoptera litura (F.) (Lepidoptera: Noctuidae) (JSTOR, 2007 \& Shepard et al., 1987). Lama hidup imago mencapai 9 hari (Prabowo, 1996). Di Filipina, tingkat parasitisasi dari hasil pengumpulan inang $S$. litura di lapangan secara umum mencapai 50\% (Torreno, 1980), dan di Indonesia dilaporkan mencapai 70\% (Pudjianto \& Sartiami, 1996), walaupun keberhasilan parasitisasi tersebut tidak dijelaskan dengan spesifik sebagai keberhasilan pengendalian hayati.

Menurut Vinson dan Iwantsch (1980), keberhasilan hubungan inang dengan parasitoid dipengaruhi berbagai hal, yaitu lokasi habitat inang, lokasi inang, penerimaan inang, dan kesesuaian inang. Perilaku pemilihan inang di antaranya dipengaruhi oleh biologi dan fase inang yang diserang, faktor fisik, dan ciri morfologi inang yang spesifik (Vinson, 1985). Preferensi terhadap instar larva inang Heliothis zea dan $H$. virescens dilaporkan pada pemarasitan oleh parasitoid Microplitis croceipes (Hopper \& King, 1984), inang Plutella xylostella oleh parasitoid Cotesia plutellae (Kawaguchi \& Tanaka, 1999), dan inang Mythimna separate oleh parasitoid C. kariyai (Fujiwara et al., 2000).

Perilaku oviposisi dan superparasitisasi dipengaruhi oleh kepadatan populasi inang (Van Alphen \& Jervis, 1996). Kecenderungan imago betina parasitoid meningkatkan oviposisi terjadi bila sediaan jumlah inang terbatas dalam jangka waktu yang relatif lama (Vinson, 1985). Superparasitisasi dapat terjadi karena parasitoid tidak mampu mengenali inang yang telah diparasit. Kejadian superparasitisasi ini mengakibatkan ketidakefektifan parasitisasi karena dapat mengurangi tingkat keberhasilan hidup parasitoid yang berkembang dalam tubuh inang (Godfray, 1994). Perilaku oviposisi juga bergantung

${ }^{1}$ Departemen Proteksi Tanaman, Fakultas Pertanian, IPB, Jl. Kamper, Kampus IPB Darmaga, Bogor 16680 
pada umur parasitoid (Drost \& Carde, 1992). Parasitoid muda lebih aktif mencari inang dibandingkan dengan parasitoid yang lebih tua. Pada $M$. croceipes umur parasitoid dapat mempengaruhi pembentukan pupa dan persentase imago yang keluar dari pupa inang $H$. zea (Harrison et al., 1993). Penelitian ini bertujuan menentukan efisiensi pemarasitan S. manilae melalui pemilihan peletakan telur pada larva $S$. litura instar tertentu, potensi superparasitisasi, pengaruh kepadatan populasi inang, dan pengaruh umur parasitoid di laboratorium. Perolehan informasi tersebut diharapkan dapat menjadi dasar pengetahuan dalam membantu praktik pengendalian hayati.

\section{METODE PENELITIAN}

\section{Pemeliharaan dan perbanyakan serangga percobaan. Penelitian ini dilaksanakan di} Laboratorium Departemen Proteksi Tanaman, Fakultas Pertanian Institut Pertanian Bogor (IPB), pada kondisi lingkungan laboratorium suhu 24,5-32 ${ }^{\circ} \mathrm{C}$, kelembapan nisbi udara $65-85 \%$ dan pencahayaan ruangan $\pm 12: 12$ terang-gelap.

Parasitoid S. manilae dan inang S. litura diambil dengan cara mengumpulkan populasi larva $S$. litura yang berasal dari pertanaman talas di daerah Bogor, kemudian dipelihara di laboratorium. Larva diberi pakan daun talas pada instar II dan III dan kedelai pada instar lanjut ad lib. Larva terparasit dan tidak terparasit dipisahkan. Pemeliharaan larva dan pupa dilakukan pada kotak plastik berukuran $35 \mathrm{~cm}$ x 27 $\mathrm{cm} \times 7 \mathrm{~cm}$ berventilasi kain kasa. Larva tidak terparasit digunakan sebagai sumber sediaan perbanyakan inang, sedangkan larva terparasit digunakan sebagai sumber sediaan parasitoid. Parasitoid diperbanyak dengan menggunakan larva inang larva alami $S$. litura. Imago parasitoid maupun inang diberi pakan tambahan berupa larutan 10\% madu encer. Imago S. litura dipelihara dalam kurungan kasa dan plastik berbingkai kayu berukuran $50 \mathrm{~cm} \times 50 \mathrm{~cm} \times 40 \mathrm{~cm}$, sedang imago parasitoid dipelihara didalam kurungan jenis yang sama berukuran $30 \mathrm{~cm}$ x $30 \mathrm{~cm}$ x $30 \mathrm{~cm}$.

Pemilihan inang S. litura oleh parasitoid S. Manilae. Parasitoid betina S. manilae diambil dari imago yang baru keluar dari pupa, kemudian dipasangkan dengan imago jantan, dipelihara dengan cara seperti diuraikan di atas, serta dipaparkan pada inang berbagai instar larva $S$. litura di dalam satu kurungan pemeliharaan parasitoid. Kelompok larva masing-masing berisi 30 ekor instar I hingga instar V diletakkan pada sepucuk tanaman kedelai. Kelima kelompok larva tersebut diletakkan secara acak di dalam satu kurungan, kemudian dipaparkan selama 3 jam pada pagi hari (waktu pemaparan optimal berdasarkan hasil uji pendahuluan) terhadap sepasang imago parasitoid berumur 4 hari. Parasitoid dipuasakan dari pemarasitan satu hari sebelum perlakuan. Pascapemaparan, larva inang dibedah. Larva dinyatakan terparasit bila ditemukan telur parasitoid berada di dalam tubuh inang. Pengamatan dilakukan 10 kali. Preferensi inang dihitung dari persentase parasitisasi parasitoid pada tubuh setiap instar larva dengan rumus sebagai berikut:

$$
\begin{aligned}
& \text { Persentase } \\
& \text { parasitisasi }
\end{aligned}=\frac{\sum \text { larva terparasit }}{\Sigma \text { larva yang dipaparkan }} \times 100 \%
$$

Superparasitisasi dan keberhasilan perkembangan parasitoid di dalam tubuh larva inang. Sejumlah larva inang yang sama seperti di atas untuk masingmasing instar I-V dipaparkan selama 3 jam pada seekor imago betina parasitoid umur 4 hari di dalam kurungan plastik berbentuk silinder bertutupkan kain kasa diameter $10 \mathrm{~cm}$ dan tinggi $25 \mathrm{~cm}$. Persentase parasitisasi dihitung dengan cara yang sama seperti di atas. Telur yang berjumlah lebih dari satu dari setiap larva terparasit juga dihitung untuk menentukan tingkat superparasitisasi. Perlakuan pemaparan diulang 10 kali. Persentase superparasitisasi dihitung sebagai berikut:

\section{$\Sigma$ larva terparasit lebih} dari satu telur

Persentase superparasitisasi $=\frac{}{\Sigma \text { larva terparasit }} \times 100 \%$

Pada pengamatan kelangsungan hidup parasitoid, perlakuan pemaparan larva terhadap parasitoid dilakukan dengan cara yang sama seperti pada perlakuan superparasitisasi. Hanya saja, kelompok larva inang hasil pemaparan dipelihara lebih lanjut di dalam kotak plastik, diberi pakan daun kedelai ad lib hingga terbentuk imago parasitoid. Persentase keberhasilan hidup parasitoid dinyatakan 
sebagai keberhasilan hidup telurnya dan berkembang hingga imago, dihitung dengan rumus sebagai berikut:

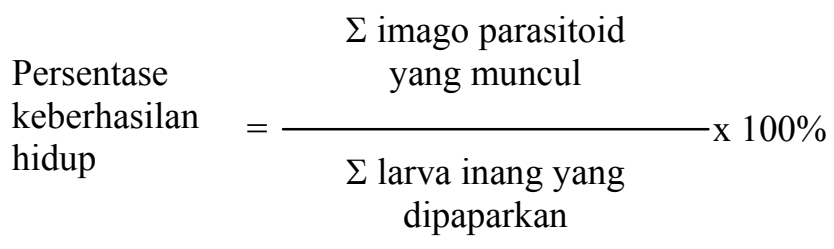

Kepadatan jumlah inang parasitoid terhadap efisensi pemarasitan. Imago parasitoid jantan dan betina yang baru keluar dari pupanya dipasangkan dan dimasukkan ke dalam sebuah kurungan plastik silinder seperti di atas. Di dalam setiap kurungan berisi masing-masing 10, 20, 30, 40 larva inang instar II yang diletakkan di atas pucuk daun kedelai. Pemaparan larva terhadap parasitoid dilakukan selama 12 jam mulai pagi hingga sore hari. Pemaparan larva inang baru dilakukan setiap hari dengan menggunakan imago parasitoid yang sama sampai imago tersebut mati. Setelah perlakuan pemaparan, parasitoid tidak diberi inang sampai perlakuan hari berikutnya. Larva hasil pemaparan dibedah dengan cara seperti diuraikan di atas. Perlakuan pemaparan diulang 10 kali. Persentase parasitisasi dan superparasitisasi pada setiap kepadatan inang dihitung dengan cara sama seperti di atas. Parasitisme optimal dihitung hanya dari larva terparasit oleh satu telur. Keperidian imago dihitung dengan menjumlahkan seluruh telur yang diletakkan selama hidupnya.

Pengaruh umur parasitoid terhadap efisensi pemarasitan. Imago parasitoid betina yang baru keluar dari pupanya dipasangkan dengan jantan berumur dua hari dan dimasukkan ke dalam sebuah kurungan plastik silinder seperti di atas. Di dalam kurungan tersebut dipaparkan 30 larva inang instar II yang diletakkan di atas pucuk daun kedelai selama 3 jam. Setelah perlakuan pemaparan, parasitoid tidak diberi inang sampai perlakuan hari berikutnya. Imago parasitoid tersebut dimasukkan ke dalam kurungan setiap hari, dimulai hari pertama sampai hari ke-9. Larva hasil pemaparan dipelihara sampai keluar imago parasitoid dengan cara seperti diuraikan di atas. Perlakuan pemaparan diulang 10 kali. Persentase keberhasilan hidup imago dihitung dengan cara sama seperti di atas. Jumlah pupa parasitoid yang berhasil berkembang di dalam tubuh larva inang dicatat. Persentase keberhasilan hidup pupa parasitoid juga dihitung dengan rumus sebagai berikut:

Persentase pupa $=\frac{\begin{array}{c}\Sigma \text { pupa parasitoid } \\ \text { yang muncul }\end{array}}{\begin{array}{c}\Sigma \text { larva yang } \\ \text { dipaparkan }\end{array}} \times 100 \%$.

Rancangan percobaan dan analisis data. Untuk setiap perlakuan pemaparan, percobaan disusun dalam rancangan acak lengkap. Perlakuan pada setiap percobaan diulang 10 kali seperti diuraikan masingmasing di atas. Data yang diperoleh dari hasil pengamatan diolah dengan program sidik ragam STATISTIX 8 yang dilanjutkan dengan uji Tukey (Steel \& Torrie, 1980).

\section{HASIL DAN PEMBAHASAN}

Pemilihan inang $S$. litura oleh parasitoid $S$. manilae. Perilaku pelepasan parasitoid dengan memberikan pilihan landas untuk oviposisi pada lima kelompok larva inang berbeda instar ditunjukkan pada Tabel 1. Imago betina parasitoid melakukan oviposisi nyata tertinggi pada larva inang instar III, yaitu

Tabel 1. Pemilihan instar inang S. litura sebagai media oviposisi parasitoid S. manilae

\begin{tabular}{|c|c|}
\hline Instar larva inang & Persentase oviposisi ${ }^{a}$ \\
\hline I & $9,3 \pm 1,8 \quad \mathrm{c}$ \\
\hline II & $22,3 \pm 2,3 \quad b$ \\
\hline III & $41,7 \pm 3,4 \quad$ a \\
\hline IV & $0,7 \pm 0,4 \quad \mathrm{~d}$ \\
\hline $\mathrm{V}$ & $\begin{array}{ll}0 & \mathrm{~d}\end{array}$ \\
\hline
\end{tabular}

${ }^{a}$ Rerata \pm galat populasi dalam lajur yang sama yang diikuti oleh huruf yang sama tidak berbeda nyata (Uji Tukey, $\alpha=0,05)$. 
mencapai $42 \%$ dibandingkan pada larva instar II yang hanya separuhnya. Pilihan oviposisi oleh parasitoid lebih rendah ditunjukkan pada larva inang instar I dan paling rendah pada larva inang instar IV, sedangkan parasitoid sama sekali tidak melakukan oviposisi pada instar lanjut. Keadaan ini menunjukkan bahwa parasitoid memilih oviposisi pada larva inang instar III diikuti instar II.

Apabila ditinjau dari sudut hambatan fisik dalam proses oviposisi, imago parasitoid diduga lebih sulit meletakkan telur pada larva inang instar lanjut yang berukuran relatif lebih besar, karena larva mudah bergerak, sering bereaksi menyerang atau menghindar terhadap perilaku oviposisi parasitoid sebagai tanda perlawanan terhadap tindakan peletakan telur (Doutt et al., 1989). Selain itu larva instar lanjut diduga memiliki lapisan kutikula yang lebih tebal sehingga lebih sulit ditembus oleh ovipositor parasitoid dibandingkan larva instar awal (Chapman, 1998). Hopper \& King (1984) melaporkan bahwa parasitoid $M$. croceipes dapat menemukan inang tetapi tidak meletakkan telur pada larva Heliothis spp. instar lanjut. Menurut McCutcheon \& Harrison (1987), parasitoid $M$. croceipes berlimpah pada tanaman kedelai dan parasitoid ini lebih menyukai larva instar III, sedangkan $M$. rufiventris menyukai larva instar I dan larva instar II dari H. zea. Begitu pula parasitisasi parasitoid C. plutellae dilaporkan lebih banyak pada larva P. xylostella instar II dan III dibandingkan instar IV (Kawaguchi \& Tanaka, 1999). Khafagi \& Hegazi (2004) melaporkan bahwa keberhasilan pengendalian ditentukan oleh parasitoid $M$. rufiventris yang memilih instar larva muda $S$. littoralis sebagai inangnya.

Secara umum kecenderungan endoparasitoid meletakkan telur pada larva instar tertentu, biasanya instar awal atau larva berukuran lebih kecil telah dilaporkan oleh beberapa peneliti. Pemilihan ini diduga terjadi karena induk memiliki naluri untuk mempertahankan atau melestarikan keturunannya. Brunson (1937) melaporkan bahwa induk prasitoid Tiphia popolliavora lebih banyak meletakkan telur pada larva inang instar III yang berpotensi menghasilkan parasitoid betina dibandingkan larva instar II. Jones (1982) juga menyatakan bahwa telur yang diletakkan oleh parasitoid Heterospilus prosopidus pada larva berukuran besar menghasilkan keturunan betina. Tilman \& Cate (1993) juga menyatakan bahwa keturunan parasitoid Bracon molitor banyak muncul dari larva Anthonomus grandis grandis berukuran relatif lebih kecil dibandingkan keturunan betina yang dihasilkan dari larva berukuran lebih besar ketika diamati saat imago meletakan telur.

Parasitoid synovigenic (parasitoid yang meletakkan telur sepanjang hidupnya yaitu sejak hari kemunculannya dari pupa hingga mati) juga melakukan perilaku oviposisi tetapi tidak untuk meletakkan telur melainkan untuk melukai inangnya dan menggunakan cairan tubuh dari hasil pelukaan sebagai pakannya. Rosenhein \& Rosen (1992 dalam Van Alphen \& Jervis, 1996) menyatakan bahwa imago parasitoid menusukkan ovipositornya untuk meletakkan telur pada larva instar awal berukuran relatif lebih besar dan melukai larva berukuran kecil kemudian digunakan sebagai pakan untuk mempertahankan kelanjutan hidupnya untuk memproduksi telur.

Parasitisisi dan superparasitisasi parasitoid di dalam tubuh larva inang. Hasil pemarasitan larva S. litura dengan paparan inang jumlah tertentu tanpa pemberian pilihan masih menunjukkan bahwa parasitoid S. manilae meletakkan telur tertinggi pada

Tabel 2 Tingkat parasitisasi, superparasitisi dan tingkat keberhasilan hidup parasitoid S. manilae di dalam tubuh larva $S$. litura ${ }^{\text {a }}$

\begin{tabular}{cccc}
\hline Instar larva inang & Parasitisasi (\%) & Superparasitisasi (\%) & Keberhasilan hidup (\%) \\
\hline I & $37,7 \pm 2,4 \mathrm{~b}$ & $11,4 \pm 2,9 \mathrm{~cd}$ & $3,7 \pm 1,2 \mathrm{bc}$ \\
II & $47,3 \pm 5,6 \mathrm{ab}$ & $15,1 \pm 3,4 \mathrm{c}$ & $16,3 \pm 2,5 \mathrm{a}$ \\
III & $56,0 \pm 4,0 \mathrm{a}$ & $31,1 \pm 2,9 \mathrm{~b}$ & $8,7 \pm 1,7 \mathrm{~b}$ \\
IV & $14,3 \pm 2,1 \mathrm{c}$ & $52,1 \pm 5,7 \mathrm{a}$ & $0 \pm 0 \mathrm{c}$ \\
V & $0 \pm 0 \mathrm{~d}$ & $0 \pm 0 \quad \mathrm{~d}$ & $0 \pm 0 \mathrm{c}$ \\
\hline
\end{tabular}


larva instar III diikuti larva instar II, walaupun tingkat parasitisasi keduanya tidak berbeda nyata (Tabel 2). Tingkat parasitisasi terendah sangat nyata terdapat pada larva inang instar IV dan tidak terjadi pemarasitan pada larva inang instar V. Tingkat superparasitisasi terendah terjadi pada pemarasitan larva instar I tidak berbeda nyata dengan larva instar II, dan berturut-turut berbeda nyata dengan pemarasitan larva instar III dan instar IV (Tabel 2). Tingkat superparasitisasi tertinggi ditunjukkan pada paparan larva inang instar IV. Tingginya tingkat parasitisasi dan rendahnya tingkat superparasitisasi dapat diselaraskan melalui percobaan terpisah yang dapat ditunjukkan bahwa keberhasilan kelangsungan hidup parasitoid nyata tertinggi diperoleh dari pemeliharaan larva terparasit instar II dibandingkan larva instar III maupun larva instar I (Tabel 2). Pemarasitan pada paparan larva instar IV dan V tidak menghasilkan pupa maupun imago parasitoid.

Pada percobaan ini S. manilae meletakkan telur pada larva inang S. litura instar III dan II yang diperkirakan memiliki ukuran tubuh medium. Menurut Van Alphen \& Jervis (1996) parasitoid koinobion pada umumnya menyukai inang berukuran tubuh medium. Rajapakse et al. (1985) melaporkan bahwa larva instar III Spodoptera frugiperda adalah instar yang paling sesuai diparasit Microplitis manilae. Pada inang larva instar III, parasitoid diduga relatif lebih mudah melakukan peletakan telur karena reaksi fisik inang kurang berarti dibandingkan instar lanjut.

Kemungkinan lain ialah parasitoid berperilaku memilih inang berdasarkan ukuran inang (Vinson, 1985). Inang yang lebih kecil kurang disukai sebagai media peletakan telur mengingat kesesuaian inang berpengaruh terhadap keberhasilan hidup parasitoid. Pada percobaan ini ditunjukkan bahwa keberhasilan hidup parasitoid paling baik terjadi pada pemarasitan larva inang instar II. Sesuai dengan pernyataan Van Alphen \& Jervis (1996) bahwa kemampuan parasitoid bertahan pada inang yang relatif lebih besar biasanya lebih baik daripada inang yang lebih kecil, karena ketersediaan nutrisi pada inang tersebut lebih memadai dibandingkan pada inang berukuran lebih kecil. Sebaliknya parasitoid tidak banyak atau bahkan tidak meletakkan telur pada inang instar lanjut diduga karena periode hidup larva instar lanjut tidak selaras dalam memenuhi waktu perkembangan larva parasitoid di dalam tubuh inang. Menurut Pudjianto
\& Sartiami (1996), perkembangan parasitoid dari telur sampai dengan imago membutuhkan waktu rata-rata 12 hari, sedangkan Tampenawas (1981) menyatakan bahwa rata-rata stadium larva S. litura 16 hari yang dapat dilalui dengan 5-6 instar. Dengan demikian larva instar II diduga memiliki waktu lebih panjang dan sesuai untuk pertumbuhan dan perkembangan parasitoid dibandingkan dengan instar lanjut yang memiliki waktu yang relatif lebih pendek dalam memberikan kesempatan larva tumbuh dan berkembang di dalam tubuh inang.

Superparasitisasi merupakan fenomena imago parasitoid betina meletakkan telur pada inang yang telah diparasit oleh spesies lain atau oleh individu imago itu sendiri, yang berarti bahwa di dalam tubuh inang terdapat lebih dari satu telur parasitoid (Doutt et al., 1989). Kejadian superparasitisasi pada parasitoid soliter kurang menguntungkan bagi pertumbuhan dan perkembangan parasitoid (Harvey et al., 1993). Di dalam tubuh inang akan terjadi kompetisi nutrisi antarlarva parasitoid yang berhasil menetas dari telur, menyebabkan kedua larva mati atau satu individu dapat berkembang dengan pertumbuhan tidak optimal sehingga terjadi penurunan kebugaran parasitoid yang berhasil muncul menjadi imago (Godfray, 1994). Selain itu kematian larva parasitoid dapat diakibatkan oleh tekanan fisiologi ataupun serangan fisik satu dengan lainnya. Tekanan fisiologi terjadi ketika peletakan telur, imago menyuntikkan toksin atau sekresi zat racun yang dapat membunuh larva parasitoid. Serangan fisik terutama dilakukan oleh larva parasitoid instar awal yang saling menyerang parasitoid lain di dalam tubuh inang yang sama dengan menggunakan alat mulut madibelnya (Van Alphen \& Jervis, 1996). Dengan demikian pada percobaan ini dapat ditunjukkan bahwa tingkat parasitisasi yang tinggi dan tingkat superparasitisasi yang rendah pada larva instar II diduga berkaitan erat dengan tingginya keberhasilan hidup parasitoid di dalam tubuh larva inang.

Pengaruh ketersediaan jumlah inang $S$. litura terhadap parasitisasi $S$. manilae. Jumlah paparan larva inang mempengaruhi kemampuan peletakan telur dan meningkatkan keperidian parasitoid. Efisiensi parasitisasi dapat ditunjukkan oleh tingkat parasitisasi optimal (60\%) dengan tingkat superparasitisasi tidak terlalu tinggi (27\%) yang diperoleh dari paparan larva 20 ekor, dan pada 
keadaan ini imago rata-rata meletakkan telur 25 telur per hari dengan rata-rata keperidian 185 ekor per imago yang dilampaui dalam waktu 6-10 hari (Tabel 3). Jumlah paparan larva lebih sedikit atau lebih besar dari 20 ekor menghasilkan tingkat parasitisasi optimal lebih rendah dibandingkan paparan 20 ekor. Tingkat parasitisasi optimal pada paparan larva 10 dan 30 ekor tidak berbeda nyata, dan tingkat parasitisasi optimal terendah terjadi pada paparan larva tertinggi (40 ekor). Tingkat superparasitisasi tertinggi diperoleh pada paparan larva paling sedikit (10 ekor) yaitu mencapai $46 \%$ dan perlahan-lahan mengalami penurunan sejalan dengan meningkatnya pertambahan jumlah paparan larva, dan tingkat superparasitisasi terendah dicapai pada paparan larva tertinggi (40 ekor) yang hanya $15 \%$. Keperidian tertinggi dan jumlah telur yang diletakkan per hari dicapai oleh seekor imago betina parasitoid yang dilepas pada jumlah paparan larva 20 ekor, sebaliknya keperidian terendah diperoleh dari imago yang dilepas pada jumlah paparan larva 10 ekor.

Lama hidup imago parasitoid $S$. manilae dilaporkan rata-rata 6-8 hari (Shepard et al., 1991), tetapi bila diberi pakan madu imago dapat bertahan hidup hingga 9 hari (Pujianto \& Sartiami, 1996). Parasitoid ini diduga termasuk serangga synovigenic, yaitu telur yang berkembang di dalam alat reproduksinya tidak seluruhnya matang dan siap untuk diletakkan, dan sebagian telur-telur tersebut perlahanlahan berkembang selama hidup imago (Jervis \& Copland, 1996). Di lapangan, imago sering memerlukan pakan pada cairan tubuh inang, embun madu atau bunga untuk memenuhi potensi reproduksinya. Menurut Prabowo (1996), kemampuan bertahan hidup yang lebih lama dapat menghasilkan keturunan yang lebih banyak. Hasil percobaan ini juga menunjukkan bahwa keperidian yang tinggi diperoleh dari imago yang mengalami masa hidup lebih lama.

Efisiensi parasitisasi bagi parasitod soliter seperti S. manilae dapat ditunjukkan melalui data tingkat parasititisasi optimal yaitu keberadaan larva terparasit oleh hanya satu telur. Sebaliknya superparasitisasi merupakan pengurangan tingkat efisiensi pemarasitan. Vinson (1985) juga menyatakan bahwa superparasitisasi terjadi bila imago betina belum terbiasa membedakan atau mendiskriminasi inang, serta berada di lingkungan keberadaan inang terbatas dalam jangka waktu yang relatif lama. Diskriminasi inang oleh imago parasitoid betina sangat bergantung pada pengalaman pemilihan inang dan pengaruh lingkungan (Van Giessen et al., 1993). Menurut Godfray (1994) superparasitisasi seharusnya tidak terjadi pada keadaan inang terpapar dalam jumlah banyak. Keadaan superparasitisasi yang tinggi dengan keperidian yang rendah pada paparan 10 ekor larva, diduga parasitoid memaksakan diri untuk meletakkan telur walaupun inang sangat terbatas dan jumlah telur yang sedikit diletakkan sebagai akibat oosorption. Liu \& Morton (1986 dalam Godfray, 1994) menduga bahwa parasitoid memilih meletakkan telur lebih dari satu di dalam tubuh inang yang ada daripada mati dengan menyisakan telur di dalam ovarinya, walaupun kemungkinan keberhasilan hidup

Tabel 3. Tingkat parasitisasi optimal, superparasitisasi, dan keperidian parasitoid S. manilae hasil perlakuan dengan pemaparan jumlah inang tertentu.

\begin{tabular}{cccccc}
\hline $\begin{array}{l}\text { Jumlah } \\
\text { paparan } \\
\text { larva inang } \\
\text { (ekor) }\end{array}$ & $\begin{array}{c}\text { Lama hidup } \\
\text { betina parasitoid } \\
\text { (hari) }\end{array}$ & $\begin{array}{c}\text { Keperidian } \\
\text { (butir } \\
\text { telur/9) }\end{array}$ & $\begin{array}{c}\text { Jumlah telur } \\
\text { (butir/9/hari) }\end{array}$ & $\begin{array}{c}\text { Parasitisasi optimal } \\
(\%)\end{array}$ & $\begin{array}{c}\text { Superparasitisasi } \\
(\%)\end{array}$ \\
\hline 10 & $4-11$ & $74,3 \pm 9,4 \mathrm{c}$ & $12,4 \pm 0,5 \mathrm{~d}$ & $41,3 \pm 0,9 \mathrm{~b}$ & $46,2 \pm 0,9 \mathrm{a}$ \\
20 & $6-10$ & $185,5 \pm 9,4 \mathrm{a}$ & $24,7 \pm 0,4 \mathrm{a}$ & $59,7 \pm 0,1 \mathrm{a}$ & $27,1 \pm 1,1 \mathrm{~b}$ \\
30 & $5-8$ & $135,3 \pm 6,8 \mathrm{~b}$ & $20,8 \pm 0,6 \mathrm{~b}$ & $44,7 \pm 1,2 \mathrm{~b}$ & $19,6 \pm 0,5 \mathrm{c}$ \\
40 & $5-9$ & $133,7 \pm 7,0 \mathrm{~b}$ & $18,8 \pm 0,5 \mathrm{c}$ & $35,5 \pm 1,2 \mathrm{c}$ & $14,9 \pm 0,6 \mathrm{~d}$
\end{tabular}

$\bar{a}$ Rerata \pm galat populasi dalam lajur yang sama yang diikuti oleh huruf yang sama tidak berbeda nyata (Uji Tukey, $\alpha=0,05)$. 
keturunannya sangat kecil. Prabowo (1994) menyatakan bahwa imago parasitoid mempunyai mekanisme penyerapan telur (oosorption atau ovisorption) jika tidak menemukan inang yang tepat untuk diparasit.

Pada hasil percobaan ini paparan larva 20 ekor per betina menunjukkan pemarasitan yang menguntungkan bagi parasitoid itu sendiri. Hal ini diduga bahwa parasitisasi optimal yang tinggi memberikan potensi keberhasilan hidup keturunannya yang tinggi. Selain itu paparan inang yang sesuai dapat meningkatkan keperidian imago parasitoid dan diduga ada kaitannya dengan terhindarnya dari perilaku ovisorption.

\section{Pengaruh umur parasitoid terhadap efisensi} pemarasitan. Secara umum ada kecenderungan bahwa induk parasitoid berumur muda lebih banyak menghasilkan keturunan dan perlahan-lahan menurun dengan bertambahnya umur (Gambar 1). Tingkat keberhasilan tertinggi munculnya imago hasil pemarasitan ditunjukkan oleh parasitoid berumur 2 hari, yaitu mencapai $26 \%$ tidak berbeda nyata dengan hasil pemarasitan parasitoid umur $1,3,4,5,6$, dan 7 hari, tetapi berbeda nyata dengan hasil pemarasitan parasitoid umur 8 dan 9 hari yang hanya mencapai $10 \%$ dan 13\%. Tingkat keberhasilan imago ini memiliki kecenderungan yang sama.

Menurut Drost \& Carde (1992), umur parasitoid mempengaruhi perilaku oviposisi. Parasitoid muda lebih aktif mencari inang dibandingkan parasitoid yang lebih tua. Umur parasitoid M. croceipes dapat mempengaruhi pembentukan pupa, presentase imago yang muncul dari pupa, dan nisbah kelamin keturunan yang berhasil dipelihara dari larva $H$. zea terparasit (Harrison et al., 1993). Pada dasarnya perkembangan larva parasitoid di dalam tubuh inang sangat ditentukan oleh komposisi nutrisi darah inang sebagai nutrisi larva parasitoid (Thompson et al., 2005). Tingkat keperidian juga dipengaruhi oleh umur parasitoid, yaitu semakin tua umur parasitoid, jumlah telur yang dihasilkan semakin menurun (Kumar et al., 1990). Hal ini menunjukkan bahwa kemampuan peletakan telur parasitoid $S$. manilae yang bersifat synovigenic pada awal hingga pertengahan periode oviposisi relatif tidak dipengaruhi oleh umur imago, dan pembentukan pupa bergantung pada keberhasilan tumbuh kembang larva yang pada akhirnya sebagai

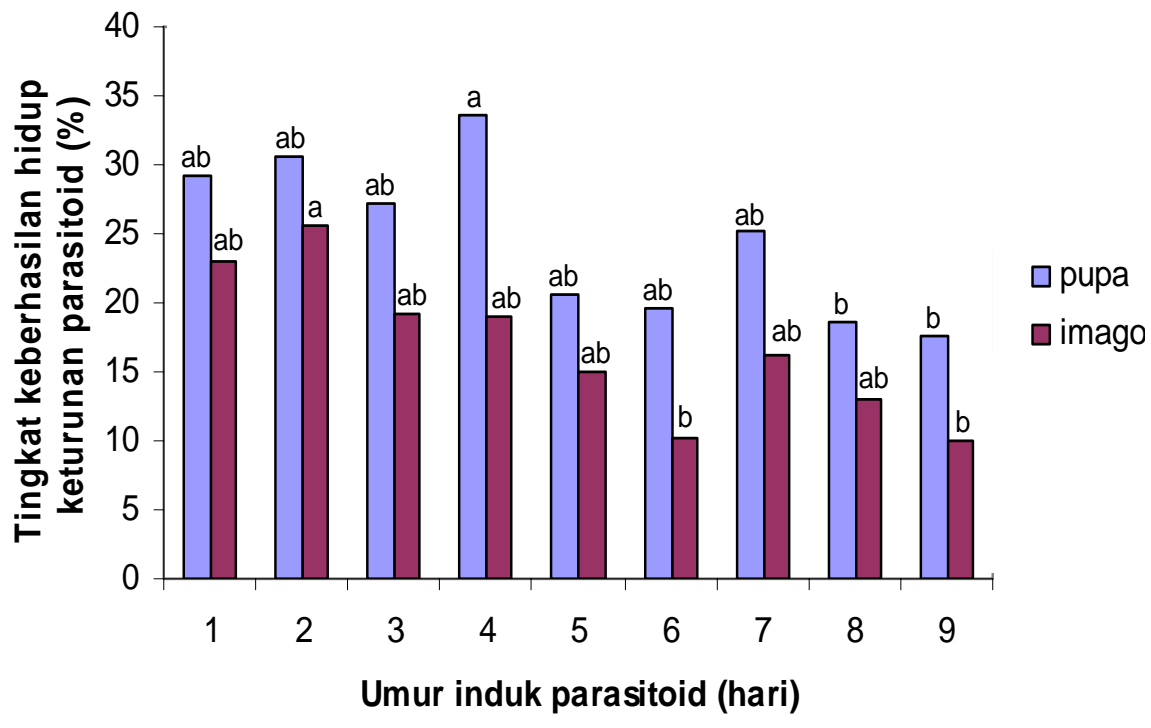

Gambar 1. Tingkat keberhasilan hidup keturunan parasitoid S. manilae hasil pemarasitan imago pada jenjang umur tertentu.

Keterangan: huruf yang sama di atas kelompok diagram yang sama tidak berbeda nyata (uji Tukey, $\alpha=0,05$ ). 
penentu keberhasilan kemunculan imago.

\section{SIMPULAN}

Parasitoid S. manilae memilih untuk meletakkan telur pada larva inang instar III $S$. litura. Superparasitisasi terendah dijumpai pada larva instar I dan II terparasit. Tingkat keberhasilan hidup parasitoid tertinggi diperoleh bila induk parasitoid landas pada larva instar II. Efisiensi parasitisasi tertinggi terjadi pada kerapatan 20 larva inang instar II. Umur imago parasitoid 1-7 hari memberi peluang keberhasilan hidup sama pada keturunannya.

\section{SANWACANA}

Pada kesempatan ini diucapkan terima kasih kepada Kantor Menteri Negara Riset dan Teknologi, Dewan Riset Nasional Republik Indonesia yang telah memberi bantuan dana riset. Ucapan terima kasih juga disampaikan kepada Dwi Kurniawati S.P., Hidayatulloh S.P., dan Rini Darwati S.P. yang telah membantu pelaksanaan penelitian ini.

\section{DAFTAR PUSTAKA}

Brunson, M.H. 1937. The influence of the instars of the host larvae on the sex of the progeny of Tiphia popolliavora. Roh. Science. 86:197.

Chapman, R. F. 1998. The Insects Structure and Function. Cambridge Univerwsity Press. Cambridge. United Kingdom.

Doutt, R.L., D.P. Annecke, \& E. Tremblay. 1989. Biologi dan hubungan hospes parasitoida. Dalam Teori dan Praktek Pengendalian Biologis. Huffaker dan Messenger, ED. Terjemahan Mangoendiharjo. UI Press. Jakarta.

Drost Y.C. \& R.T. Carde. 1992. Influence of host deprivation of egg load and oviposition behaviour of Brachimeria intermedia, a parasitoid of gypsy moth. Physiol. Entomol. 17 (3): 230-234.

Fujiwara C., J. Takabayashi, \& S. Yano. 2000. Oviposition experience on a host-infested plant affects flight and antennal searching behavior of
Cotesia kariayi toward the host-plant complex. Entomol. Exp. et Aplicata. 97: 251-256.

Godfray H.C.J. 1994. Parasitoid Behavioral and Evolutionary. Princeton University Press, New Jersey.

Harrison W.W., D.A. Herbert, \& D.D. Hardee. 1993. Effect of parasitoid and host age on oviposition and emergence of Microplitis croceipes Hymenoptera: Braconidae) an endoparasitoid of Helicoverpa zea ( Lepidoptera: Noctuidae). J. Ent. Sci. 28(4): 343-349.

Harvey J.A., I.F. Harvey, \& D.J. Thompson. 1993. The effect of superparasitism on development of the solitary parasitoid wasp Venturia canescens (Hymenoptera: Ichneumonidae). Ecol. Entomol. 18: 203-208.

Hopper K.R. \& E.G. King. 1984. Preference of Microplitis croceipes (Hymenoptera: Braconidae) for instar and species of Heliothis (Lepidoptera: Noctuidae). Environ. Entomol. 13: 1145-1150.

Jervis M.A. \& W.J.W. Copland. 1996. The life cycle. In Insect Natural Enemies. Practical Approach to their Study and Evaluation. Jervis M, Kidd N. Ed. Chapman \& Hall. London.

Jones W.T. 1982. Sex ratio and host size in a parasitoid wasps. Behav. Ecol. Sociobiol. 10: 207-210.

JSTOR. 2007. http://link.jstor.org. http://www.knowledgebank.irri.org/Beneficials/ Scientific name Snellenius Microplitis manila e_Ashmead. htm.

Kawaguchi M. \& T. Tanaka. 1999. Biological characteristic of a larval endoparasitoid, Cotesia plutellae (Hymenoptera: Braconidae): Host stage preference, subsequent sex ratio of progeny and mate location of males. Appl. Entomol. Zool. 34(2): 213-221.

Khafagi W.E. \& E.M. Hegazi. 2004. Is the host or parasitoid in control?: Effects of host age and 
temperature on pseudoparasitization by Microplitis rufiventris in Spodoptera littoralis. J. Insect physiol. 50(7): 577-584.

Kumar P., A. Kumar, \& P. Sengupta. 1990. Parasitoid of uzi fly, Exorista sorbillans Wiedemann (Diptera: Tachnidae) effect of host and parasitoid age on parasitization and progeny production of Nesolynx thymus. Indian $J$. Sericulture. 29(2): 208-212.

McCutcheon G.S. \& W. Harrison. 1987. Host range and development of Microplitis rufiventris (Hymenoptera: Braconidae), an imported parasitoid of several lepidopterous pests. Environ. Entomol. 16: 855-858.

Prabowo A.H. 1994. Biologi parasitoid Snellenius (=Microplitis) manilae Ashmead (Hymenoptera: Braconidae) pada inang ulat grayak Spodoptera litura Fabr. (Lepidoptera: Noctuidae). Laporan Masalah Khusus. Jurusan Hama dan Penyakit Tumbuhan, Fakultas Pertanian, Institut Pertanian Bogor.

Pudjianto \& D. Sartiami. 1996. Biologi parasitoid Snellenius (=Microplitis) manilae (Ashmead), pada inang ulat grayak, Spodoptera litura (Fabricius). Makalah disampaikan pada Seminar Hasil-Hasil Penelitian, Institut Pertanian Bogor. 9 Desember 1996.

Rajapakse R.H.S., T.R. Ashley, \& V.H. Waddill. 1985. Biology and host acceptance of Microplitis manilae (Hymenoptera: Braconidae) raised on fall armyworm larvae, Spodoptera frugiferda (Lepidoptera: Noctuidae). Florida Entomol. 68: 653-657.

Shepard B.M., A.T. Barion, \& J.A. Litsinger. 1987. Helpful insects, spiders, and pathogens. National Rice Research Institute. Manila. Philippines.

Steel R.G.D. \& J.H. Torrie. 1980. Principles and Procedures of Statistics: A Biometrical Approach. $2^{\text {nd }}$ ed. McGraw-Hill, New York.
Tampenawas, S.A. 1981. Biologi Spodoptera (Prodenia) litura Fabr. (Lepidoptera: Noctuidae) pada dua varietas kedelai. Laporan Masalah Khusus. Jurusan Hama dan Penyakit Tumbuhan, Fakultas Pertanian, Institut Pertanian Bogor, Bogor.

Thompson S.N., R.A. Redak, \& L.W. Wang. 2005. Host nutrition determines blood nutrient composition and mediates parasite developmental success: Manduca sexta L. parasitized by Cotesia congregata (Say). J. Exp. Biol. 208(4): 625-635.

Tilman P.G. \& J.R. Cate. 1993. Effect of host size on adult size and sex ratio of Bracon mellitor (Hymenoptera: Braconidae). Environ. Entomol. 22 (5): 1161-1165.

Torreno H.S. 1990. Parasitization behavior and efficiency of the Braconid Microgaster manilae (Ashmead), against the cutworm Spodoptera litura (Fabr.). Tropical Pest Management. 36: 128-130.

Van Alphen J.J.M. \& M.A. Jervis. 1996. Foraging behaviour. In Insect Natural Enemies. Practical Approach to their Study and Evaluation. Jervis M, Kidd N. Ed. Chapman \& Hall. London.

Van Giessen V.A., W.J. Lewis, L.E.M. Vet, F.L. Wackers, \& W.A. van Giessen. 1993. The influence of host site experience on subsequent flight behaviour in Microplitis croceippes (Cresson) (Hymenoptera: (Braconidae). Biological Control. 3: 75-79.

Vinson SB. 1985. The behavior of parasitoids. In Comprehensive Insect Physiology Biochemistry and Pharmacology. Vol. 9. Behaviour. Kerkut GA, Gilbert LI. Ed. Pergamon Press. Oxford. 